\title{
Freiburger Schule und Christliche Gesellschaftslehre
}

Joseph Kardinal Höffner und die Ordnung von Wirtschaft und Gesellschaft Hrsg. v. Nils Goldschmidt u. Ursula Nothelle-Wildfeuer

[The Freiburg School and Christian Social Teaching. Joseph Cardinal Höffner and the Order of Economy and Society.]

Published in German.

The economic and social ethics of Joseph Cardinal Höffner can be understood to a large extent by referring to its roots in

Freiburger Schule und Christliche

Gesellschaftslehre

Herausgegeben von

NILS GOLDSCHMIDT und

URSULA NOTHELLE-WILDFEUER

Walter Eucken Inssitu

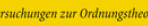

Mohr Siebeck

2010. XIII, 390 pages. UOrd 59

SBN 978-3-16-151484-5

DOI 10.1628/978-3-16-151484-5

eBook PDF $69,00 €$ ordoliberalism. This book analyzes both the biographical and theoretical relations between the Freiburg school of economics and Höffner's thinking as it represents Christian social teaching. The focus lies on the question of how it is possible to develop a social theory which is economically sound, ethically responsible and suitable for application in our modern global society.

Nils Goldschmidt ist Professor für Kontextuale Ökonomik und ökonomische Bildung an der Universität Siegen.

Ursula Nothelle-Wildfeuer ist ordentliche Professorin für Christliche Gesellschaftslehre an der Albert-Ludwigs-Universität Freiburg.

\section{Order now:}

https://www.mohrsiebeck.com/en/book/freiburger-schule-und-christliche-gesellschaftslehre-9783161514845?no cache=1 order@mohrsiebeck.com

Phone: +49 (0)7071-923-17

Fax: $+49(0) 7071-51104$ 